\title{
The Use of Halliday's Interpersonal Metafunction in Creating Informative and Persuasive Advertisement: A Multimodal Analysis of AirAsia 2015 Commercial
}

\author{
Rosyid Anwar, International Development Program East Java
}

\begin{abstract}
Multimodality makes communication no longer limited to verbal expressions. The meaning formation of multimodal text involves different modalities. In advertisements, language, image and other modalities are used to create meaning in a marketing communication. One of advertisements that applies multimodality concept is AirAsia 2015 commercial. It is argued that the use of image is more prevalent in contemporary advertisement, while the use of language is more uncommon. In order to make the message effectively conveyed, the linguistic mode needs to serve the most essential function of language as represented in Halliday's metafunctions. Despite its ability to convey message, language as a linguistics mode needs to be combined with other mode to form the meaning of the advertisement. The use of linguistic and para-linguistic modes is essential to create an informative and persuasive nature of advertisement and to better promote the product and the service.
\end{abstract}

Keywords: advertisement; multimodality; systemic functional linguistics; visual communication

\section{Introduction}

Advertisement has become an inseparable part from everyday life. Kotler and Keller (2012) defined advertisements as any paid and non-personal form of promotion which aimed to promote products and service as well as ideas and values of the advertisers. In terms of how it is presented to the audiences, advertisement is divided into two types. The first type of advertisement is the one that can only be seen, while the second one is the kind of advertisement which is presented to be seen and heard (McMahan, 1957). The second definition refers to commercial, a means of promoting product on non-printed media. Commercial is also defined as any advertisement which appears on TV and radio depicting a brand during a break (Engeseth, 2009). By involving both linguistic and para-linguistic modes, commercial can better convey meaning to the audience and thus becomes prevalent nowadays. In the era of technology, commercials are no longer confined in merely radio and television broadcast, but also in the form of other audiovisual media, including those that appear on internet media.

According to Kotler and Keller (2012), advertisement is a form of marketing communication. Based on the expected response of audience, marketers further divide advertisement into informative and persuasive advertisement. Informative advertisement is an advertisement which is intended to create consumers' awareness and product knowledge, while persuasive advertisement is an advertisement which is aimed to create consumers' liking and preference (Kotler \& Keller, 2012). Many contemporary advertisements now implement both informative and persuasive approach to better promote their products and services. There are more and more challenges faced by advertisers. In addition, the nature of advertisement has been rapidly changing to adapt with the modern world. In the era of technology, there is a significant shift in the audience behaviors that they choose to be less text-oriented readers. Instead of relying heavily on the text, advertisement also involves images, music, and even moving pictures. It is believed that image becomes more prevalent in contemporary advertisements.

Perloff (in Fulton, 2005) argued that there is a considerable reduction of words used in advertisement. It is simply unpractical to put the extremely long and tedious text on the screen since the audience will find it more difficult to understand the message of the advertisement. Furthermore, Jewitt (2005) remarked that it is getting harder to maintain language as the dominant part of advertisement. In addition, the use of words in advertisement becomes less dominant because advertisement has to consider the limit of the duration and the frame. Longer 
duration means higher spending. Thus, the digital advertisement is more preferred nowadays (Engeseth, 2009). The duration can be shortened when various modes can be combined to create the whole meaning.

Kress (2010) defined a mode as a semiotic resource used for creating meaning that socially shaped. Meaning is created from various modes. Kress (2010) believed that a combination of different modes is the most common form of human communication. Each mode cannot profoundly convey meaning because of its partiality, and thus it has to be combined with other modes. Linguistic mode is put in sequence, organized, and shared across cultures. Meanwhile, image is believed to be a mode that suits the interest of the viewers and often leads to various interpretations (Kress, 2010). At this point, it is believed that abstract mode like image cannot stand on its own and is better be combined with linguistic mode. Since image is a more dominant element of an advertisement, language has to be used in certain way, so it can serve its fundamental function and reinforce the image function.

One of many commercials that implement the use of informative and persuasive approaches is the commercial of AirAsia. AirAsia is a Malaysian low-cost airline founded in 2001. The motto is Kini Siapapun Bisa Terbang (Now Everyone Can Fly) that indicates the high commitment of this airline in providing full service with low fares. It is claimed that AirAsia was established after the incident of $9 / 11$ and global financial crisis (AirAsia, n.d.). It is interesting to note that the airline has survived on the greatest depression of airline industry and now become the most prominent low-cost airline. AirAsia has gained several awards from Skytrax as the Asia's best low-cost airline, and the world's best low-cost airline as well (Skytrax, n.d.).

The recent success of the airplane is believed to be closely related to the power of the promotional campaign that has been done, especially the campaign that has been appeared on digital media. AirAsia actively promotes its service on TV, website, and even on YouTube. This paper aims to analyze the use of multimodality in AirAsia 2015 commercial. The commercial is entitled AirAsia Indonesia People, published on 1 November 2015 (AirAsia, n.d.). It is argued that the way the meaning is conveyed through the multimodal text eventually define the informative or persuasive nature of advertisement. The informative and persuasive nature of advertisement is essential to successfully promote product and service. This paper aims to analyze how marketing communication is done in advertisements, and how it affects the expected response of the audience.

\section{Methodology}

The current multimodal analysis is conducted using qualitative method. Qualitative method is an approach utilized to analyze data using in-depth understanding and descriptive explanation (Wray \& Bloomer, 2012). This article draws a number of social semiotic tools in the form of linguistic and para-linguistic modalities. The term modality itself is originated from the linguistic concept of statements truth values which are linguistically realized (Kress \& Van Leeuwen, 2006). To analyze the formation of meaning, this article draws on the idea of linguistic metafunction proposed by Halliday. Halliday (in Kress \& Van Leeuwen, 2006) argued that the grammar of a language does not function as a set of rules to produce correct sentences, but it functions as a meaning making resource.

\subsection{Systemic functional linguistics}

Halliday proposed the concept of systemic functional linguistics that there are no fundamental functions of language in human communication. It is argued that communication always has a goal or a motif, and language is used as a means to achieve the goal (Halliday \& Matthiessen, 2014). Furthermore, Halliday explained about language metafunctions. There are mainly three functions that a language must serve, namely the ideational, interpersonal, and textual metafunction.

Interpersonal metafunction concerns with the social aspect of language. Humans use language not only as a means of communicating something, but also as a way of enacting personal and social act. Halliday and Matthiessen (2014) stated that humans interact by making 
propositions, informing, questioning as well as giving an order and making an offer. Furthermore, interpersonal metafunction also focuses on the relationship between the speaker, the message, and the audience. According to Halliday and Matthiessen (2014), speakers put themselves in a particular speech role when communicating and wish their audience to adapt to their role and to give respond.

The core components of communication are subject and finite. The finite element is divided into three degrees of polarity namely the low, median, and high polarity (Halliday \& Matthiessen, 2014). In Halliday's conception of language functions, there is an expression of statement known as declarative category, which is used by meaning maker to state or assert something. Another function that plays an important role in advertisement is imperative category that creates a more persuasive nature of advertisement. Halliday and Matthiessen (2014) also considered communication as a rhetorical exchange in which the participants are exchanging commodities in the form of products and services, as well as information. Declarative category is the major element of advertisement with informative nature, while the imperative category creates a more persuasive nature of advertisement (Anwar, 2016).

\subsection{The grammar of visual design}

Visual communication is another important aspect found in the concept of modality. Kress and Van Leeuwen (2006) stated that this concept takes the depiction of participation to account. Participants are usually the people depicted in a visual image, closely related to the concept of subject in Halliday's functional linguistics. There are three aspects of visual communication that define the nature of an advertisement.

The first aspect is gaze that consists of demand and offer. Gaze is the major aspect that defines the informative and persuasive sense of an advertisement. Kress and Van Leeuwen (2006) further argued that the aspect of gaze appears every time people are depicted. They also divided gaze into two categories namely the demand and the offer gaze. Halliday (in Kress \& Van Leeuwen, 2006: 118) explained the gaze as follows:

"Demand indicates that the gaze is directly addressed to the viewers, while offer indicates the absence of direct gaze. Offer usually makes the represented participant an object of contemplation, whose impersonal relationship with the viewer is meant to be that of informative one. Meanwhile, demand indicates a personal and social affinity between the represented participant and the viewers. This is meant to invite the viewer to an imaginary relation."

The second aspect of interpersonal metafunction in visual communication is distance. Kress and Van Leeuwen, (2006: 124) defined distance as follows:

"Distance indicates the different level of intimacy between the viewers and the viewed. A close-up shot is considered as an intimate shot, since the distance between the participant and the viewer is kept not to be too far. A medium shot is a shot that depicts the participant at the waist or knees, signaling a socially interactive relationship."

The last aspect of interpersonal metafunction is the angle of camera. Eye level angle is really prevalent in commercial. Eye level indicates the absence of power, in which the participant and the viewer are considered as equal (Kress \& Van Leeuwen, 2006).

\section{Findings and discussion}

Language helps humans to communicate and satisfy their interest. Promoting product and service is one of many functions served by language. Goddard (1998) argued that language used in advertisement is different from that of everyday language. The verbal expression is closely related to the interest of the advertiser. However, many advertisements no longer rely heavily on the use of language since the utilization of image now becomes more prevalent. It poses a challenge to consider the limited number of the words being used in the advertisement. Excessive use of words will make the advertisement less communicative that the message may not be effectively delivered.

Visual communication is another essential factor related to the effectiveness of an advertisement in conveying message and persuading prospective customers. Jewitt (2005) 
pinpointed that writing becomes image if it is too small or too big to be expressed by verbal language. Not only it represents message that cannot be expressed by verbal language, Kress and Van Leeuwen (2010) remarked that image have to be able to serve representational and communicational functions. The combination of visual communication and verbal communication forms multimodal text, which is believed to better convey message from the meaning maker to the audience.

The linguistic aspect of the AirAsia commercial creates a more informative nature of commercial. It uses a lot of declarative which indicates that information becomes the main concern of the communication. Halliday and Matthiessen (2014) divided the degree of polarity into low, median, and high. The use of certain degree of polarity results from the way people speak differently, whether they want to assert something or suggest something. The finite of the statements such as berawal, mewujudkan, jalani, and menjadi give a signal that the speaker aims to build an assertive and authoritative explanation representing the voice of the company, since they all have high degree of polarity. There is one imperative speech indicating an offer, in which the speaker tries to promote the product and service. The finite is memberikan, which means give. The imperative speech role of...dengan tetap memberikan yang terbaik (by giving the best [product and service]) is used to refer to the offer. The only use of imperative is related to persuasive aspect of the linguistic mode of the commercial.

The use of the predominantly high polarity declarative speech in commercial is purposed to influence the response of the audience. Chan (1996) stated that this is due to the targeted response that involves logical and rational thinking process. By explaining the historical background and the vision of the company objectively in the statement of Berawal dari sebuah harapan... and Untuk mewujudkan semua impian, the commercial aims to create awareness and knowledge as explained in Kotler and Koller's first hierarchy. The informative nature is also presented in the technical explanation regarding the company's commitment and loyalty to ketelitian (precision) and komunikasi (communication). The way the company tries to go through such operational technicality in the advertisement is interesting. But it is inevitable that airline industry heavily emphasizes the technical and procedural aspects for the sake of safety and security. This is in accordance with Kotler and Keller's (2012) explanation related to informative advertisement which usually takes the importance of safety and security into account. Commercial and promotional aspects are not the only essential elements of airline business. Thus, this is the reason why the commercial includes some technical details.

Table 1: The distribution of speech role related to interpersonal metafunction

\begin{tabular}{|c|c|c|c|}
\hline \multirow[t]{2}{*}{ Role } & \multicolumn{2}{|c|}{ Commodity Exchange } & \multirow{2}{*}{$\begin{array}{l}\text { Expected } \\
\text { response }\end{array}$} \\
\hline & Goods \&Service & Information & \\
\hline Declarative & - & Berawaldarisebuahharapan & Logical \\
\hline Declarative & - & Untukmewujudkansemuaimpian & Logical \\
\hline Declarative & - & $\begin{array}{l}\text { Komitmenakanketelitiandankomunikasi, } \\
\text { kami jalanisetiaphari, sebagailoyalitas }\end{array}$ & Logical \\
\hline Declarative & - & $\begin{array}{ll}\text { Suatukebanggaanbagi } & \text { kami } \\
\text { untukmenjadilebihbaik }\end{array}$ & Logical \\
\hline $\begin{array}{l}\text { Imperative } \\
\text { (Offer) }\end{array}$ & $\begin{array}{l}\text { dengantetapmemberikan } \\
\text { yang terbaik }\end{array}$ & - & Emotional \\
\hline
\end{tabular}

Adapted from Halliday and Matthiessen (2014: 136)

The para-linguistic mode lies mainly on the visual depiction. In terms of gaze, the commercial uses both direct and indirect gaze. The use of indirect gaze aims to give the commercial a more informative sense. This is because indirect gaze makes the participant becomes an object of information and contemplation (Kress \& Van Leeuwen, 2006). The use of indirect gaze is used every time the crews of the airplane are portrayed, since information 
regarding the technical details of the flight is the aspect that is communicated. This depiction exemplifies the use rational and logical response proposed by Chan (1996). Another visual element used to depict the information is the use of low and eye level angle. Low angle indicates that the participant exercise power over the audience while eye level is used to maintain the communicative aspect (Kress \& Van Leeuwen, 2006). These visuals element are perfectly combined with high polarity declarative speech to further strengthen the informative and authoritative nature of the commercial.

In contrary, the direct gaze that is mainly used creates a more persuasive sense of the commercial. Audience is invited to become a part of the communication that is indicated by the gesture such as saluting with index and middle finger that is typical to invitation gesture. Kress and Van Leeuwen (2006) stated that invitation gesture is used when the participant wants to address the audience directly and to involve them in an ongoing communication. The participant also shows a smiling facial expression which is defined as an invitation to make a good relationship with a social affinity.

In terms of distance, the participants always keep a medium shot to maintain the interactive social relationship. The commercial even uses close-up to build intimacy with the audience. The angle of the camera involves the use of the eye level angle. Eye level angle indicates equality (Kress \& Van Leeuwen, 2006), and it is used to avoid detachment for the sake of communicative aspect. Medium distance is prominently used because the para-linguistic aspect of the language aims to create a more persuasive nature. Hence, social distance has to be kept as minimum as possible, despite the absence of engagement. The use of visual element exemplifies the idea of emotional response proposed by Chan (2006), stating that commercial is mainly used to create favorable feeling and emotion. The use of distance, gaze and angle are described as follows:

Table 2: Visual imagery

\begin{tabular}{|c|c|c|c|c|}
\hline Image & Gaze & Distance & Angle & Expected Response \\
\hline & Indirect & Medium & Eye Level & Logical \\
\hline & Indirect & Medium & Eye Level & Logical \\
\hline & Direct & Close-up & Eye Level & Emotional \\
\hline & Indirect & Medium & Low Angle & Logical \\
\hline & Indirect & Medium & Eye Level & Logical \\
\hline & Indirect & Medium & Eye Level & Logical \\
\hline & Indirect & Medium & Eye Level & Logical \\
\hline & Direct & Medium & Eye Level & Emotional \\
\hline & Direct & Medium & Eye Level & Emotional \\
\hline
\end{tabular}


Table 2, cont.

\begin{tabular}{|l|l|l|l|l|}
\hline & Direct & Medium & Eye Level & Emotional \\
\hline & Indirect & Medium & Low Angle & Logical \\
\hline
\end{tabular}

\section{Conclusion}

It can be concluded that informative and persuasive nature are both needed in the commercial because the advertiser expects the audience to give both logical and emotional response positively. The analysis indicates that there is a remarkable degree of consistency. Informative nature presented by linguistic mode is more prevalent in the commercial, consisting of four high polar declaratives and one imperative creating awareness and knowledge. The visual imagery in form of gaze, distance and angle also indicates more informative nature, consisting of seven logical responses and four emotional responses.

\section{References}

AirAsia Indonesia People Campaign TVC 30s. Available at https://www.youtube.com/watch?v=N5kf9hLnB0Y. (Accessed 7 February 2018).

A-Z Airline Award winners 2017. Available at
http://www.worldairlineawards.com/Awards/a_z_airline_winners.html. (Accessed 7 February 2018).

Chan, K.K.W. 1996. Chinese viewers' perception of informative and emotional television commercials. International Journal of Advertising, 15(2), 152-166.

Engeseth, S. 2009. The fall of $P R$ \& the rise of advertising. (n.p.): Stefan Engeseth Publishing.

Fulton, H. et al. 2005. Narrative and media. Cambridge: Cambridge University Press.

Goddard, A. 1998. The language of advertising. London: Routledge.

Halliday, M.A.K \& Matthiessen, M.I.M. 2014. Halliday's introduction to functional grammar (4th ed). New York: Routledge.

Jewitt, C. 2005. Multimodality, "reading" and "writing" for the 21st century. Discourse: Studies in the Cultural Politics of Education, 26(3), 315-331.

Kotler, P. \& Keller, K.L. 2012. Marketing management (14th ed). New Jersey: Pearson Ed.

Kress, G.\& Van Leeuwen, T. 2006. Reading images. New York: Routledge.

Kress, G. 2010. Multimodality: A social semiotic approach to contemporary communication. New York: Routledge.

McMahan, H. W. 1957. The television commercial. New York: Hastings House Publishers

The Beginner's Guide to AirAsia: Hi, We're AirAsia! Available at https://www.AirAsia.com/my/en/about-us/hi-we-are-AirAsia.page\#. (Accessed 7 February 2018).

Wray, A. \& Aileen B. 2012. Projects in linguistics and language studies. London: Hodder Education. 